\title{
Application of Microscopy and X-ray Diffraction in Optimization of the Production of NiTi Alloy by Powder Metallurgy
}

Pavel Novák ${ }^{1}$, Andrea Školáková ${ }^{1}$, Vladimír Vojtěch ${ }^{1}$, Anna Knaislová $^{1}$, Petr Pokorný ${ }^{1}$, Hynek Moravec ${ }^{1}$, Jaromír Kopeček $^{2}$, Miroslav Karlík ${ }^{3}$, Tomáš František Kubatík ${ }^{4}$

${ }^{1}$ Institute of Chemical Technology, Prague, Department of Metals and Corrosion Engineering, Technická 5, 16628 Prague 6, Czech Republic, E-mail: panovak@vscht.cz

${ }^{2}$ Institute of Physics of the ASCR, v. v. i., Na Slovance 2, 18221 Prague 8, Czech Republic, E-mail: kopecek@fzu.cz ${ }^{3}$ Czech Technical University in Prague, Faculty of Nuclear Sciences and Physical Engineering, Department of Materials, Trojanova 13, 12000 Prague 2, Czech Republic, E-mail: Miroslav.Karlik@fjfi.cvut.cz

${ }^{4}$ Institute of Plasma Physics AS CR, v.v.i., Za Slovankou 1782/3, 18200 Prague 8, Czech Republic, E-mail: kubatik@ipp.cas.cz

This paper describes the dependence of microstructure of NiTi shape memory alloy on the conditions of nonconventional powder metallurgy processing routes - reactive sintering of compressed Ni+Ti powder mixture and mechanical alloying with consequent compaction by Spark Plasma Sintering. First method was chosen as the process enabling to yield the high-purity NiTi alloy, while the second one aimed to reach the ultrafine-grained microstructure. The microstructure and phase composition of the products are compared in this work. The positive effects of high heating rate $\left(>300 \mathrm{~K}\right.$.min-1) and high temperature (at least $900{ }^{\circ} \mathrm{C}$ ) on the reactive sintering process were recognized. Microstructure of the product is composed by NiTi matrix with dispersed Ti2Ni particles. Similar microstructure can be also obtained by mechanical alloying for at least 120 min and consequent compaction by Spark Plasma Sintering.

Keywords: powder metalurgy, NiTi, mechanical alloying, reactive sintering

\section{Acknowledgement}

This research was financially supported by the Czech Science Foundation, project No. 14-03044S.

\section{References}

[1] VOJTĚCH, D., KUBÁSEK, J., NOVÁK, P. (2013). Corrosion properties of the superelastic shape memory Ni-Ti alloy for medical implants. In: Manufacturing Technology, Vol. 13, No. 3, pp. 409-414. UJEP. Czech Republic.

[2] ELAHINIA, M.H., HASHEMI, M., TABESH, M., BHADURI, S.B. (2012). Manufacturing and processing of NiTi implants: A review. In: Progress in Materials Science, Vol. 57, No. 5, pp. 911-946. Elsevier. Netherlands.

[3] FOROOZMEHR, A., KERMANPUR, A., ASHRAFIZADEH, F., KABIRI, Y. (2011). Investigating microstructural evolution during homogenization of the equiatomic NiTi shape memory alloy produced by vacuum arc remelting. In: Materials Science and Engineering A, Vol. 528, No.27, pp. 7952-7955. Elsevier. Netherlands.

[4] SADRNEZHAAD, S.K., RAZ, S.B. (2005). Interaction between Refractory Crucible Materials and the Melted NiTi Shape-Memory Alloy. In: Metallurgical and Materials Transactions B, Vol. 36B, pp. 395-403. Springer. Germany.

[5] NOVÁK, P., MICHALCOVÁ, A. MAREK, I., VODĚROVÁ, M., OJTĚCH, D. (2012). Possibilities of the observation of chemical reactions during the preparation of intermetallics by reactive sintering. In: Manufacturing Technology, Vol. 12, No. 13, pp. 197-201. UJEP. Czech Republic.

[6] NOVÁK, P., VODĚROVÁ, M., HENDRYCH, R., KUBATÍK, T., MICHALCOVÁ, A., VOJTĚCH, D. (2013). Preparation of aluminium-based quasicrystals. In: Manufacturing Technology, Vol. 13, No. 3, pp. 390-394. UJEP. Czech Republic.

[7] NOVÁK, P., MICHALCOVÁ, A., MAREK, I., MUDROVÁ, M., SAKSL, K., BEDNARČÍK, J., ZIKMUND, P., VOJTĚCH, D. (2013). On the formation of intermetallics in Fe-Al system - An in situ XRD study. In: Intermetallics, Vol. 32, pp. 127-136. Elsevier. Netherlands.

[8] MASSALSKI, T.B. (1990). Binary Alloy Phase Diagrams, ASM, Materials Park. 